Humaniora. Czasopismo Internetowe

Nr 1 (33)/2021, ss. 49-68

\author{
TOMASZ KUPŚ \\ Uniwersytet Mikołaja Kopernika w Toruniu \\ Wydział Filozofii i Nauk Społecznych, Instytut Filozofii \\ Katedra Historii Filozofii, Filozofii Systematycznej i Etyki \\ e-mail: kups@umk.pl \\ ORCID: 0000-0001-6773-1180 \\ DOI: https://doi.org/10.14746/h.2021.1.3
}

\title{
Idea Boga w późnych pismach Immanuela Kanta*
}

\begin{abstract}
Kant's position on the problem of God is radicalized under the influence of transcendental philosophy's evolving project. The weakening position of physico-theology and the growing importance of moral theology are possible ways of describing the shift in perspective between the pre-critical period writings and the critical period writings. The separation of the area of cognition and action excludes the possibility of formulating theodicy in a classical form. God, as only a conceived idea, and its meaning is firmly grounded in practical philosophy, in which the presentation of the law is a sufficient condition for moral behaviour. In such a model, God is only an idea, but a fully functional one. This could be noticed mostly in the Opus postumum, where in analogy to God's practical idea, Kant deduces the transcendental ether's existence. Ether is not just a hypothesis for Kant; it is not just a 'temporary' or 'contingent' assumption made ad hoc to explain a particular experience. Still, it is a fundamental and indelible condition, a conditio sine qua non of experience in general. The non-hypothetical matter of heat (ether) is the transcendental condition of all experience, though it does not cease to be an 'intelligible thing', an 'idea'. The status of this idea is entirely 'non-theoretical'. Kant writes about the ether similarly as he writes about the idea of God, which is only conceivable but at the same time it maintains a strong 'non-theoretical'status. The Kantian idea of God is strongly objectified. It is not a 'product' of reason, but rather something 'perceived' by reason, a strictly theistic idea (as Erich Adickes claims).
\end{abstract}

* Niniejszy artykuł jest poszerzoną wersją referatu o tym samym tytule, wygłoszonego na Katolickim Uniwersytecie Lubelskim Jana Pawła II, podczas XI Polskiego Zjazdu Filozoficznego (Lublin, 9-14 września 2019 roku). 
Kant's statements, characteristic for the Opus postumum, in which God is identified with moral law, of course give grounds to suppose that the deification of practical reason can be understood as a final stage in the long process of anthropologizing God. However, these statements also allow us to consider practical reason as a new source of what is given.

Keywords: Immanuel Kant, the idea of God, practical philosophy, transcendental philosophy, philosophical theology, Opus postumum

\section{Uwagi wstępne}

Niektóre tematy były podejmowane przez Kanta doraźnie, a poświęcone im rozprawy możemy traktować jako incydentalne ${ }^{1}$. Inne jednak wydają się stałym motywem albo zadaniem, z którym filozof zmaga się wciąż na nowo. Do tych ostatnich z pewnością można zaliczyć temat Boga². Nie wystarczy powiedzieć, że „Bóg” funkcjonuje w pismach Kanta w różnych kontekstach, a wobec tego w różnych znaczeniach: jako pojęcie teologii racjonalnej, idea bądź ideał czystego rozumu, przedmiot czystej religii rozumowej lub wiary kościelnej. Znaczenie ma dopiero tendencja, którą można dostrzec w tej różnorodności. Po części tendencja ta została już rozpoznana i opisana jako „rozmycie” pojęcia Boga ${ }^{3}$. W niniejszym artykule zwrócę uwagę na jeden jej aspekt, a mianowicie na przesunięcie akcentu w kierunku Boga jako idei.

Rozważania dotyczące Boga w filozofii Kanta kumulują się w dwóch głównych obszarach: teologii i etyki ${ }^{4}$. W pierwszym Bóg jawi się jako niedowiedziony przedmiot metafizyki tradycyjnej, w drugim zaś jako konieczny postulat rozumu praktycznego. Chociaż istnieją podstawy, by bronić odrębności tych obszarów, powołując się na chronologię publikacji dzieł królewieckiego filozofa, to jednak można je omawiać także jako komplementarne perspektywy w filozofii Kanta.

${ }^{1}$ Przykładem może być stanowisko Kanta dotyczące teodycei. Pierwsze reakcje Kanta w tej sprawie sprowokowane zostały trzęsieniem ziemi, które pod koniec roku 1755 zniszczyło Lizbonę. Kant wyraził swoje stanowisko w trzech rozprawkach (wydanych w 1756). Esej z roku 1791 (O daremności wszelkich filozoficznych prób w teodycei) wydaje się ostatecznym zakończeniem tego wątku, w sposób charakterystyczny dla tego okresu twórczości filozofa. Perspektywa teoretyczna i perspektywa praktyczna wydają się zmierzać w przeciwnych kierunkach, tworząc wrażenie niezależnych od siebie obszarów badań.

${ }^{2}$ Por. Kant-Lexikon, red. M. Willaschek, J. Stolzenberg, G. Mohr, S. Bacin, De Gruyter, Berlin-Boston 2015, s. $887 \mathrm{nn}$.

${ }^{3}$ Por. A. Cortina, Die Auflösung des religiösen Gottesbegriffs im Opus postumum Kants, „Kant-Studien” 1984, nr 3(75).

${ }^{4}$ Por. G. Sala, Kant und die Frage nach Gott. Gottesbeweise und Gottesbeweiskritik in den Schriften Kants, De Gruyter, Berlin-New York 1990; K. Fischer, Immanuel Kant und seine Lehre, Winter, Heidelberg 1957; J. Bohatec, Die Religionsphilosophie Kants in der Religion innerhalb der Grenzen der bloßen Vernunft, Hoffman und Campe, Hamburg 1938; C. Dierksmeier, Das Noumenon Religion. Eine Untersuchung zur Stellung der Religion im System der praktischen Philosophie Kants, De Gruyter, Berlin-New York 1998; R. Wimmer, Kants kritische Religionsphilosophie, De Gruyter, Berlin-New York 1990. 
Perspektywę tę, obecnie reprezentowaną m.in. przez Chrisa Firestone’a czy Stephena Palmquista, podzielam ${ }^{5}$. Dlatego analizy przedstawione w niniejszym tekście, należy traktować jako rozwinięcie i uzupełnienie stanowiska reprezentowanego przez wymienionych autorów.

\section{Idea Boga}

Biorąc pod uwagę najpierw krytykę teologii racjonalnej, a następnie etyko-teologię z lat 70. i 80., czymś zaskakującym wydaje się, widoczny w późnych pismach Kanta, powrót do pojęcia Boga ${ }^{6}$. Oczywiście fakt, że pojęcie Boga, po części, zostało wypełnione treścią, która znalazła się już w pismach przedkrytycznych, nie oznacza, że późne rozważania Kanta można uważać za porzucenie stanowiska krytycznego ${ }^{7}$. W pismach z późnych lat 80. i 90. powstały raczej warunki, w których możliwe stało się nowe ujęcie idei Boga.

Przez późne pisma Kanta rozumiem zarówno wydane przez filozofa dzieła, jak i nieopublikowane za jego życia szkice, nad którymi pracował od lat 90. niemal do śmierci. Dzieła wydane w tym okresie przede wszystkim składają się na korpus Kantowskiej filozofii praktycznej. Perspektywa ta staje się tu dominującym kluczem interpretacyjnym, także w odniesieniu do podejmowanych wcześniej przez Kanta klasycznych tematów metafizyki racjonalnej. Wydaje się nawet, że dopiero na gruncie filozofii praktycznej klasyczne tematy filozofii religii wypełnione zostają treścią, której najwyraźniej nie zdołały dostarczyć metafizyczne rozważania okresu przedkrytycznego.

„Idea”, tytułowe pojęcie niniejszego szkicu, jest w filozofii Kanta terminem wieloznacznym ${ }^{8}$. W pierwszej kolejności przez ideę rozumiem czyste pojęcie rozumu $^{9}$, a przez ideę Boga - czyste, rozumowe pojęcie Boga, któremu w Krytyce

${ }^{5}$ T. Kupś, Religia rozumowa a wiara kościelna w filozofii Immanuela Kanta, w: Filozofia Boga, cz 1: Poszukiwanie Boga, red. ks. S. Janeczek, A. Starościc, Wydawnictwo KUL, Lublin 2017, ss. 35-36.

${ }^{6}$ Kant-Lexikon, red. M. Willaschek, J. Stolzenberg, G. Mohr, S. Bacin, s. 894.

7 J. Sirovátka, Ethik und Religion bei Immanuel Kant. Versuch einer Verhältnisbestimmung, Karl Alber, Freiburg-München 2019, s. 57. Zwolennicy przeciwnego stanowiska wskazują na powrót Kanta do tematów, które podejmował w pismach przedkrytycznych (por. G. Lehmann, Kants Tugenden. Neue Beiträge zur Geschichte und Interpretation der Philosophie Kants, De Gruyter, Berlin-New York 1980, s. 112; V. Mathieu, Kants Opus postumum, Vittorio Klostermann, Frankfurt am Main 1989, s. 111), ewentualnie do argumentacji, którą posługiwał się już w pismach przedkrytycznych (por. E. Förster, Kant's Final Synthesis. An Essay on the Opus postumum, Harvard University Press, Cambridge-London 2000, s. 91; T. Kupś, Od ontoteologii do krytyki dowodu ontologicznego - ewolucja myśli Immanuela Kanta, w: Dowody ontologiczne. W 900. Rocznicę śmierci św. Anzelma, red. S. Wszołek, Kraków 2011, ss. 148-150).

${ }^{8}$ Por. Kant-Lexikon, red. M. Willaschek, J. Stolzenberg, G. Mohr, S. Bacin, s. 1114 nn.

${ }^{9}$ W Krytyce czystego rozumu Kant używa terminu „idea” w dwóch głównych znaczeniach. Po pierwsze, jako określenia mentalnej treści prezentującej się w świadomości, dla której nie ma 
czystego rozumu Kant nadał znaczenie regulatywne ${ }^{10}$. Regulatywną ideę Boga utożsamia Kant z ideałem czystego rozumu ${ }^{11}$, a więc z odpowiednikiem teologicznej idei bytu najbardziej realnego (ens realissimum ${ }^{12}$, praistoty (ens originarium), najwyższej istoty (ens summum) i istoty wszelkich istot (ens entium) ${ }^{13}$. Idei Boga, jako czystemu pojęciu, nie odpowiada żadne zjawisko, „w którym można by je było sobie przedstawić in concreto"14. Zgodnie z ustaleniami filozofii transcendentalnej, istnienie Boga jest jedynie przedmiotem spekulacji, która nie może przekształcić się w poznanie. Z tego powodu wydaje się rzeczą zadziwiającą, że interpretacje Kantowskiej teologii racjonalnej koncentrują się zwykle na istnieniu, a w mniejszym stopniu na istocie Boga ${ }^{15}$. Zapewne to właśnie negatywny rezultat krytyki spekulatywnych dowodów na istnienie Boga jest jednym z ważniejszych powodów marginalizacji, której ulega teologia w wielu wykładniach Kantowskiej filozofii religii.

Zakładam, że idea Boga od początku do końca ${ }^{16}$ pełni w filozofii Kanta ważną funkcję, niezależnie od celu i rezultatu rozważań filozofa, w których pojęcie to występuje. Niektóre z tych rozważań mają charakter apologetyczny (na przykład przedkrytyczna fizyko-teologia czy onto-teologia, albo etyko-teologia okresu

ekwiwalentu empirycznego, a więc w znaczeniu podobnym do Kartezjańskiej idei wrodzonej („Pojęcie czyste, które swe źródło ma wyłącznie w intelekcie (nie w czystym obrazie zmysłowości), zwie się notio. Pojęciem wytworzonym z notiones i przekraczającym możliwości doświadczenia, jest idea, czyli pojęcie rozumowe [Vernunftbegriff]”. KrV, A 320/B 377). Drugie znaczenie również uwzględnia fakt, że idea przekracza doświadczenie, ale w tym przypadku dodatkowo podkreśla się jej niezbędność („Przez ideę rozumiem konieczne pojęcie rozumowe, któremu dokładnie odpowiadający przedmiot nie może być dany w zmysłach”. KrV, A 327/B 383).

Pisma Kanta cytuję w tłumaczeniu polskim, według wydania: I. Kant, Dzieła zebrane, Wydanie Translatorium Filozofii Niemieckiej IF UMK pod kierunkiem Mirosława Żelaznego, t. 1-6, Wydawnictwo Naukowe Uniwersytetu Mikołaja Kopernika, Toruń 2010 nn. oraz I. Kant, Opus postumum, tłum. T. Kupś, M. Żelazny, Wydanie Translatorium Filozofii Niemieckiej IF UMK pod kierunkiem Mirosława Żelaznego, Wydawnictwo Naukowe Uniwersytetu Mikołaja Kopernika, Toruń 2019. Sigla podaję według międzynarodowego zapisu (http://www.kant-gesellschaft.de/de/ ks/Hinweise_Autoren_2018.pdf, dostęp: 30.01.2021). Numery tomów oraz stron według wydania Berlińskiej Akademii Nauk (Immanuel Kant, Gesammelte Schriften, wyd.: t. 1-22 Preussische Akademie der Wissenschaften, t. 23 Deutsche Akademie der Wissenschaften zu Berlin, od t. 24 Akademie der Wissenschaften zu Göttingen, Berlin 1900 nn.), które zostały zastosowane również w polskim wydaniu Dzieł zebranych oraz w Opus postumum Immanuela Kanta.

${ }^{10} \mathrm{KrV}, \mathrm{A} 685 / \mathrm{B} 713$.

${ }^{11} \mathrm{KrV}, \mathrm{A} 597 \mathrm{nn} / \mathrm{B} 625 \mathrm{nn}$.

$12 \mathrm{KrV}, \mathrm{A} 575 \mathrm{nn} / \mathrm{B} 603 \mathrm{nn}$.

${ }_{13} \mathrm{KrV}, 578 / \mathrm{B}$ 606. Por. KrV, A 631/B 659.

${ }^{14} \mathrm{KrV}, \mathrm{A}$ 567/B 595.

${ }^{15}$ H. Klinge, Die moralische Stufenleiter. Kant über Teufel, Menschen, Engel und Gott, De Gruyter, Berlin-Boston 2018, s. 69.

${ }^{16}$ W roku 1747, w swojej pierwszej rozprawie, Myśli o prawdziwej mierze sił żywych, Kant posługuje się głównie metafizycznym, Leibniziańskim pojęciem Boga, jako doskonałego stwórcy (GSK, AA 01:22 nn.), w notatkach z roku 1803 Bóg jest przede wszystkim ideą w systemie filozofii transcendentalnej (od początku zbioru pierwszego Opus postumum: OP, AA 21:1 nn.). 
krytycznego), inne zaś - polemiczny (zwłaszcza krytyka teologii racjonalnej, objawienia czy wiary kościelnej). Rezultaty krytyki teologii racjonalnej bez wątpienia determinują sposób, w jaki ocenia się kwestię Boga we wszystkich pismach Kanta. Nie popadając w przesadę, można chyba nawet powiedzieć, że negatywny rezultat krytyki nieomal całkowicie przesłania to, co się z niej ostaje. Tymczasem Bóg, niedowiedziony na gruncie teoretycznej filozofii, zachowuje znaczenie jako idea, której konieczność zostaje wykazana w perspektywie praktycznej: „Jest ze wszech miar koniecznym przekonać się o istnieniu Boga, ale nie aż tak znowu koniecznym, ażeby go dowodzić” ${ }^{17}$.

System idei transcendentalnych można uważać za zwieńczenie krytyki metafizyki racjonalnej. A jednak nie jest on ostatecznym przekształceniem idei Boga w pismach Kanta. Z pewnością to najważniejszy pozytywny rezultat krytyki spekulatywnych dowodów istnienia Boga oraz zawężenia perspektywy teoretycznej do granic, w jakich może być uzyskiwane poznanie naukowe, i to w wersji, dla której wzór stanowi matematyczne przyrodoznawstwo. Zawężenie to nie oznacza jednak ani redukcji wszelkiej ludzkiej aktywności do aktywności poznawczej („Musiałem więc zawiesić wiedzę, aby zrobić miejsce dla wiary”18), ani nie jest rezygnacją z racjonalności poza obrębem poznania (,[rozum praktyczny] potwierdza więc to, co [w spekulatywnym] mogło być tylko pomyślane” $\left.{ }^{19}\right)^{20}$.

Począwszy od końcowego rozdziału Krytyki czystego rozumu („Transcendentalnej nauki o metodzie”21, gdzie rozumowi praktycznemu przyznaje Kant władzę tworzenia zasad, tzn. „kanonu” dla rozumu teoretycznego ${ }^{22}$ ), Bóg staje się nieodzownym atrybutem filozofii praktycznej. Wydźwięk tego tekstu jest jasny: „Rozum czuje się zmuszony przyjąć” mądrego stwórcę świata, który może zagwarantować systematyczną jedność moralności i szczęśliwości, w przeciwnym razie człowiek „musiałby uznać prawa moralne za czcze urojenia mózgu”²3. Teologia spekulatywna zostaje wyparta przez teologię moralną̨24, zaś etyka zostaje powiązana z teologią (chociaż natura tego związku nie jest jednoznaczna i wciąż jest przedmiotem kontrowersji).

Przy wszystkich modyfikacjach, którym filozofia krytyczna uległa pod wpływem polemik, obrany w Krytyce czystego rozumu kierunek myślenia o Bogu i religii dominuje w pracach z lat 80. i 90. (od Ugruntowania metafizyki moralności, przez Krytykę praktycznego rozumu i Krytykę władzy sq̨dzenia, aż po

${ }^{17}$ BDG, AA 02:163.

${ }^{18} \mathrm{KrV}, \mathrm{B}$ XXIX-XXX.

${ }^{19} \mathrm{KpV}$, AA 06:6.

${ }^{20}$ Por. A. Tomaszewska, Filozofia religii Kanta $w$ kontekście nowożytnego racjonalizmu religijnego, „Studia z Historii Filozofii” 2020, nr 1(11), s. 124.

${ }^{21} \mathrm{KrV}$, A 795/B $823 \mathrm{nn}$.

${ }^{22}$ Por. J. Sirovátka, Ethik und Religion bei Immanuel Kant..., s. 63.

${ }^{23} \mathrm{KrV}, \mathrm{A}$ 811/B 839.

${ }^{24} \mathrm{KrV}, \mathrm{A} 814 / \mathrm{B} 842$. 
Metafizykę moralności). W tym czasie utrwala się także, obecne już w pismach przedkrytycznych, przeświadczenie Kanta, że dla samej moralności byłoby czymś niewłaściwym uzależniać ją od jakichkolwiek czynników pozamoralnych (choć od początku wyjątkiem pozostaje perspektywa najwyższego dobra, która z czasem stwarza podstawę do rozumienia religii jako nietożsamej z etyką ${ }^{25}$ ). Początkowe słowa Religii w obrębie samego rozumu można chyba uważać za podsumowanie stanowiska Kanta z początku lat 90 .:

Etyka [die Moral] - o ile opiera się na pojęciu człowieka jako istoty wolnej, lecz dlatego zarazem istoty, która sama siebie przez swój rozum wiąże bezwarunkowo prawami nie potrzebuje ani idei jakiejś innej, wyżzzej od człowieka istoty dla poznania swego obowiązku, ani pobudki innej niż samo prawo dla przestrzegania obowiązku. [...] Zatem moralność sama dla siebie (zarówno i obiektywnie, gdy chodzi o chcenie, jak i subiektywnie, gdy chodzi o możność [realizacji]) w żadnym wypadku nie potrzebuje religii, lecz na mocy czystego praktycznego rozumu wystarcza sama sobie ${ }^{26}$.

Jeśli weźmiemy pod uwagę wczesne refleksje Kanta na temat religii i etyki, to wydaje się nawet czymś trudnym do wyjaśnienia, że w pismach z lat 90. pojawia się również silnie obecna tendencja, by afirmatywnie przedstawiać związek pomiędzy etyką a teologią ${ }^{27}$. Przeciwstawienie teologii i etyki na gruncie filozofii Kanta w duchu redukcjonizmu eliminacyjnego ${ }^{28}$ wydaje się nie do utrzymania w dłuższej perspektywie, choć stanowisko to nadal znajduje swoich zwolenników ${ }^{29}$. Nawet jeśli, jak twierdzi Stephen Palmquist, Kant nie redukuje religii do etyki w sposób eliminacyjny, a wiec jeśli nie uznaje religii za jakąś „określoną formę moralności”, to mimo wszystko uważa, że moralność jest „teleologicznie niekom-

25, „[...] prawo moralne [moralische Gesetz] poprzez pojęcie najwyższego dobra jako obiektu i ostatecznego celu czystego praktycznego rozumu prowadzi do religii, tj. do poznania wszystkich obowiązków jako przykazań boskich - nie jako sankcji, tj. samowolnych, z istoty przypadkowych zarządzeń obcej woli, lecz jako istotnych praw wszelkiej wolnej woli samej przez się”. KpV, AA 05:129.

${ }^{26}$ RGV, AA 06:1.

${ }^{27}$ W latach 70. XX wieku taki sposób interpretowania filozofii religii Kanta reprezentowali między innymi Allen W. Wood i Michel Despland. Współcześnie zwolennikami tej interpretacji są np. Chris Firestone oraz Stephen Palmquist. Nie omawiam tu tego nurtu, ale odnotowuję jedynie możliwe alternatywne sposoby intepretowania relacji pomiędzy etyką i teologią w filozofii Kanta.

${ }^{28}$ To termin wprowadzony przez Palmquista do opisu relacji pomiędzy etyką i teologią w systemie filozofii Kanta. Por. S. Palmquist, Does Kant Reduce Religion to Morality?, „Kant-Studien” 1992, nr 2(83), s. 129.

${ }^{29}$ Stanowisko takie reprezentują na przykład Rem B. Edwards (Reason and Religion, University Press of America, Washington, 1979, s. 46), H. Staeps (Das Christusbild bei Kant, „Kant-Studien” 1907, nr1-3(12), s. 105) czy Ernst Cassirer (Kants Leben und Lehre, Bruno Cassirer, Berlin 1921, s. 407). W Polsce zwolennikiem tej wykładni jest Maciej Chlewicki, choć tezę „moralność jest religią” rozumie jako „podniesienie etyki do rangi religii” (Kant a problem filozofii religii, Wydawnictwo Uniwersytetu Kazimierza Wielkiego, Bydgoszcz 2012, s. 137). 
pletna”30, ponieważ stawia przed istotami rozumnymi zadanie, którego nie można zrealizować, pozostając na gruncie rzekomo niezależnej moralności. Jeśli więc w pismach z lat 90. powstaje u Kanta potrzeba odniesienia etyki do religii, to chyba głównie wskutek konfrontacji moralnego celu z faktycznością zła, zakorzenionego w ludzkiej naturze, znacznie głębiej niż Kant początkowo to zakładał ${ }^{31}$. Niezależnie od tego, w jaki sposób rozumie się ostatecznie związek pomiędzy etyką i religią, sam fakt uwzględniania takiej ewentualności można chyba rozpatrywać jako próbę urealnienia projektu filozoficznego ${ }^{32}$.

Fakt, że człowiek ujawnia radykalny pociąg do zła ${ }^{33}$ oznacza, iż do zła zdolny jest każdy i w każdej sytuacji; nie tylko niektórzy, w warunkach ekstremalnych. Skłonność do zła jest zakorzeniona w samej ludzkiej naturze i nie może być w żaden sposób usunięta. W Religii w obrębie samego rozumu czytamy:

[...] nie trzeba wcale zakładać, że ludzie [...] są już pogrążeni w złu i kuszą złym przykładem. Wystarczy, iż są obecni, że człowieka otaczają, że są ludźmi, aby wzajemnie niszczyć swoje moralne predyspozycje, deprawując się nawzajem ${ }^{34}$.

Ta przykra konstatacja skłania Kanta do przyjęcia koniecznego wsparcia moralnego postępu ludzkości, które filozof umieszcza w porządku idei religijnych:

Nawet przy dobrej woli każdego człowieka, ze względu na brak jednoczącego pryncypium, ludzie byliby narzędziami w rękach zła, oddalając się przez ciągłe waśnie od wspólnego celu, jakim jest dobro ${ }^{35}$.

Rozbieżność pomiędzy realiami warunków ograniczonego ludzkiego życia a jego moralnym celem potwierdza, że moralność prowadzi poza swoje granice (,etyka prowadzi nieodzownie do religii”36). W przedmowie do drugiego wydania Religii w obrębie samego rozumu relację pomiędzy etyką i religią Kant wyraził w metaforze koncentrycznych kręgów ${ }^{37}$. Wewnętrzny krąg reprezentuje czystą religię rozumową (inteligibilny obszar moralności), a zewnętrzny - wiarę historyczną w objawienie (faktyczną wiarę kościelną). Kiedy więc moralność wychodzi poza swoje granice i wspiera się na autorytecie wiary historycznej, nie oznacza to

${ }^{30}$ S. Palmquist, Does Kant Reduce Religion to Morality?, „Kant-Studien” 1992, nr 2(83), s. 134.

${ }^{31}$ T. Kupś, Religia rozumowa a wiara kościelna..., s. 36.

${ }^{32}$ Urealnienie nie oznacza rezygnacji z kluczowych założeń filozofii transcendentalnej. Etyka w rozumieniu Kanta nie może wynikać z doświadczenia (czerpać uzasadnienia z faktów), a autonomia woli musi pozostać zagwarantowana nawet w przypadku „tożsamości” Boga i rozumu praktycznego („,Deus in nobis”). Por. J. Sirovátka, Ethik und Religion bei Immanuel Kant..., s. 57.

${ }^{33}$ RGV, AA 06:29 nn.

${ }^{34}$ RGV, AA 06:94.

${ }^{35}$ RGV, AA 06:97.

${ }^{36}$ RGV, AA 06:6.

${ }^{37}$ RGV, AA 06:12-13. 
bynajmniej, że wykracza ku jakiejś transcendencji. Przeciwnie, opuszczenie czysto inteligibilnej sfery idei jest raczej upadkiem w faktyczność.

Jeśli chodzi o sposób rozumienia owego „jednoczącego pryncypium”, przychylam się częściowo do interpretacji Aleksandra Bobko:

[...] doskonalenie moralne, walka ze złem i wreszcie ustanowienie wiecznego pokoju to zadania, które człowiek jako racjonalny podmiot ma do wykonania w sferze moralności i polityki. Aby jednak realnie myśleć o urzeczywistnieniu celów wytyczonych przez rozum, konieczne jest założenie istnienia Boga - w tym sensie polityka, podobnie jak etyka, prowadzi ostatecznie do religii ${ }^{38}$.

Nie uważam jednak, że ta interpretacja czystej religii rozumowej prowadzi do „założenia istnienia Boga” nie tylko jako postulatu praktycznego rozumu. Gdyby tak rzeczywiście było, nie musielibyśmy wówczas przyjmować, że w Religii w obrębie samego rozumu, a być może również w innych późnych pismach, Kant odszedł od rozstrzygnięć krytyki teologii racjonalnej. W każdym razie trudno byłoby takiego stanowiska bronić. Jednoczące pryncypium, by skutecznie wypełnić swoją funkcję, może pozostać jednoczącym pryncypium tylko w idei.

Z pewnością już od Jedynej możliwej podstawy na istnienie Boga (1763) Kant uwzględnia inną, niż tylko poznawczą, perspektywę możliwego przekonania się o istnieniu Boga ${ }^{39}$. Jednak perspektywa ta w pełni zostaje zaprezentowana dopiero w filozofii praktycznej, w pismach z lat 80. i 90. To nowe stanowisko znajduje odzwierciedlenie również w nowej terminologii Kanta, w takich wyrażeniach, jak „praktyczna realność”40 (w odniesieniu do idei Boga i nieśmiertelności) czy „praktyczna konieczność”41 (w odniesieniu do wolności, prawa moralnego i imperatywu kategorycznego). Choć pojęcia te funkcjonalnie wypełniają miejsce, które opustoszało w wyniku krytyki tradycyjnych dowodów istnienia Boga ${ }^{42}$, nie są jednak żadnymi dowodami nowego typu ${ }^{43}$.

${ }^{38}$ A. Bobko, Religijny fundament filozofii politycznej Kanta?, w: Kant wobec problemów współczesnego świata, red. J. Miklaszewska i P. Spryszak, Wydawnictwo Uniwersytetu Jagiellońskiego, Kraków 2006, ss. 197-198.

39 BDG, AA 02:163.

${ }^{40}$ MS, AA 06:253; KU, AA 05:456; RGV, AA 06:5-6. Por. R. Eisler, Kant-Lexikon, Olms, Hildesheim-Zürich-New York 1994, s. 432.

${ }^{41}$ GMS, AA 04:414, 434. Por. K. Steigleder, Kants Moralphilosophie. Die Selbstbezüglichkeit reiner praktischer Vernunft, Metzler, Stuttgart-Weimar 2020; W. Brinkmann, Praktische Notwendigkeit. Eine Formalisierung von Kants Kategorischem Imperativ, Mentis, Paderborn 2003.

${ }^{42}$ H. Heine, Z dziejów religii i filozofii w Niemczech, tłum. T. Zatorski, Kraków 1997, s. $111 \mathrm{nn}$.

${ }^{43} \mathrm{O}$ moralnym dowodzie istnienia Boga (der moralische Gottebeweis) Kant nigdzie nie pisze. Jest to określenie, które zostało nadane przez interpretatorów Kantowskiej etykoteologii (Kant-Lexikon, red. M. Willaschek, J. Stolzenberg, G. Mohr, S. Bacin, s. 896 nn.). Stanowisko Kanta co do moralnej pewności istnienia Boga wyrażone w Krytyce praktycznego rozumu nie znajduje jednak potwierdzenia w późniejszych pismach (S. Palmquist, Does Kant Reduce Religion to Morality?, s. 139). 
To podejście dominuje w późnych pismach Kanta. Z jednej strony (inaczej niż początkowo) rośnie presja, by do filozofii praktycznej wprowadzić Boga (na przykład jako ,jednoczące pryncypium”), z drugiej jednak nie słabnie utrwalone w krytyce teologii racjonalnej przekonanie, że nie można owemu praktycznie realnemu Bogu przyznać żadnego innego statusu niż tylko statusu idei. Czy Bóg jako „tylko” idea to mało, czy dużo? Zakładam, że jest to nie tylko wystarczająco dużo, ale że nie ma żadnych podstaw, by oczekiwać czegokolwiek więcej ${ }^{44}$.

\section{Deus in nobis}

Dla rozumu, który działa według „przedstawiania praw”45, a więc dla rozumu praktycznego, również „tylko przedstawiony” Bóg jest wystarczającą pobudką ${ }^{46}$. Rozum nie musi zakładać żadnej siły (siły fizycznej), ale siłę przedstawioną, albowiem to, co inteligibilne (wola) może być „pobudzone” tylko przez to, co również jest tylko inteligibilne (maksyma). Innymi słowy, w inteligibilnym porządku

${ }^{44}$ Moje hipotezy traktuję jako jeden z możliwych sposobów rozumienia tożsamości rozumu praktycznego i Boga. Dyskusje na ten temat obecne są w badaniach nad filozofią religii Kanta co najmniej od publikacji Reinera Wimmera (Kants kritische Religionsphilosophie), gdzie wprost został postawiony problem „istnienia Boga w człowieku”. Por. także: G. Schwarz, Est Deus in nobis. Die Identität von Gott und reiner praktischer Vernunft in Immanuel Kants Kritik der praktischen Vernunft, Verlag TU Berlin, Berlin 2004 oraz polemika z tezą tej monografii: R. Brandt, Der Gott in uns und für uns bei Kant, w: Religion und Philosophie im Widerstreit?, red. C. Bickmann, M. Wirtz, H.-J. Scheidgen, Bautz, Nordhausen 2008.

45 „Dlatego owo doskonałe dobro nie może zaistnieć inaczej aniżeli w przedstawieniu prawa samego w sobie, pojawiającym się tylko u istot rozumnych, gdzie racją określającą ich wolę może być właśnie ono, a nie oczekiwany skutek”. GMS, AA 04:401. W Ugruntowaniu metafizyki moralności przedstawienie prawa (Vorstellung des Gesetzes) lub przedstawienie obowiązku (Vorstellung der Pflicht) jest wystarczającym dla moralnego postępowania istoty rozumnej samookreśleniem woli. Por. także GMS, AA 04:402, 407, 410 (z uwagą dotyczącą Sulzera, w przypisie), 412, 413, 427 oraz KpV, AA 05:55, 75, 80, 125, 129 , 151, 153, 157.

${ }^{46}$ Należy przy tym odróżnić praktyczne przedstawienie Boga (tzn. to przedstawienie Boga, które wytwarza rozum praktyczny) od antropomorfizmu, czyli teoretycznego przedstawienia Boga (który, jak podkreśla Kant, ,jest niezwykle niebezpieczny ze względu na nasz praktyczny stosunek do woli Bożej oraz dla samej moralności”. RGV, AA 06:168). Antropomorfizm polega na tym, że „urabiamy sobie bowiem tutaj takiego Boga, którego najłatwiej wykorzystać dla naszej korzyści i wierzymy, że zostaliśmy zwolnieni ze żmudnego, nieustannego trudu oddziaływania na to, co najbardziej wewnętrzne w usposobieniu”. RGV, AA 06:169. Przedstawienie Boga, o jakim jest tu mowa, oznacza wprawdzie, że „każdy człowiek st warza sobie B og a”, RGV, AA 06:168 (przypis dodany w wydaniu drugim), ale nie dowolnie, lecz „zgodnie z moralnymi pojęciami” (ibidem). Takie przedstawienie Boga jest ideałem wytworzonym koniecznie przez rozum, z którym musi być porównywane to, co uważamy za objawienie. Podsumowując, dodaje Kant: „[w] oparciu o samo objawienie, bez wcześniejszego pojęcia Boga w jego czystości jako probierza leżącego u podstaw, nie może być mowy o religii, a wszelkie czczenie Boga byłoby bałwochwalstwem”. RGV, AA 06:169 (przypis). 
przedstawień, tylko przedstawienie może skutecznie działać ${ }^{47}$. Takim skutecznie działającym przedstawieniem jest idea Boga jako prawodawcy i sędziego, który objawia się tylko wewnętrznie, w rozumie praktycznym, jako „głos” prawa moralnego (jako imperatyw kategoryczny ${ }^{48}$ ). W odróżnieniu od całej tradycji filozofii klasycznej epifania, o której tu mowa, nie jest żadnym poznaniem, które od początku - najpierw w kulturze greckiej, a potem w filozofii europejskiej - było utożsamiane z jakąś formą „oglądu”49. Objawienie, o którym tu mowa, nie jest zdarzeniem prezentującym się zewnętrznie, jako zjawisko na „widzialnym niebie”50, ale jest jedynie wydarzeniem, którego realność wyraża się posłuszeństwem wobec „niewidzialnego" głosu rozbrzmiewającego wewnętrznie, w rozumie praktycznym ${ }^{51}$.

Bez wątpienia ten pogląd był bliski Kantowi wcześniej. W pismach przedkrytycznych znajdujemy jego pierwsze ślady. Na pytania postawione w Marzeniach jasnowidzqcego objaśnione przez marzenia metafizyki: „Czy serce ludzkie nie zawiera bezpośrednich przepisów moralnych i czy potrzeba maszynerii aż z drugiego świata, aby je tu poruszyć zgodnie z jego własnymi określeniami?’52, filozof odpowiada: pozytywnie na pierwsze i negatywnie na drugie. Człowiek motywowany w swym postępowaniu obowiązkiem nie jest poruszany siłą „maszynerii aż z drugiego świata”. W gruncie rzeczy zarówno on sam (rozum praktyczny, nazwany tu przez Kanta „sercem”53), jak i owe „przepisy moralne” (maksymy woli) składają się na „maszynerię” w całości znajdującą się i działającą tylko w owym „drugim świecie”, w porządku inteligibilnym. Tę zmianę w nastawieniu do relacji pomiędzy moralnym działaniem a zewnętrzną motywacją Boskiego autorytetu wyrażają wszystkie Kantowskie określenia religii ${ }^{54}$.

${ }^{47}$ Człowiek, w odróżnieniu od zwierząt, dysponuje nie tylko przedstawianiami naocznymi, ale również abstrakcyjnymi. Za Schopenhauerem te pierwsze moglibyśmy nazwać teoretycznymi, te drugie zaś - praktycznymi. „Gdy przedstawienia są abstrakcyjne, pojawia się inny rodzaj motywacji. Choć postępki ludzkie zachodzą z nie mniej ścisłą koniecznością niż czyny zwierząt, to przecież dzięki temu rodzajowi motywacji - o ile ta składa się z myśli, umożliwiających decyzję wyboru (tj. uświadomiony konflikt motywów) - następuje działanie z rozmysłem, z rozwagą, według planu, maksym, w zgodzie z innymi ludźmi itd., zamiast zwykłego impulsu danego przez konkretne, naoczne przedmioty”. A. Schopenhauer, Czworaki korzeń zasady racji dostatecznej, tłum. J. Marzęcki, Antyk, Kęty 2003, s. 84.

${ }^{48} \mathrm{KpV}$, AA 05:80. Por. T. Kupś, Opus postumum Immanuela Kanta, Wydawnictwo Naukowe Uniwersytetu Mikołaja Kopernika, Toruń 2016, ss. 247-248.

49 J. Sirovátka, Ethik und Religion bei Immanuel Kant..., ss. 69-71.

${ }^{50}$ SF, AA 07:63, przypis.

51 T. Kupś, Opus postumum Immanuela Kanta, ss. 249-251.

52 TG, AA 02:372.

${ }^{53}$ Kant-Lexikon, red. M. Willaschek, J. Stolzenberg, G. Mohr, S. Bacin, ss. 1020-1022. Z pewnością zachodzi tu analogia pomiędzy Pascalem i Kantem. Por. J. Sirovátka, Ethik und Religion bei Immanuel Kant..., ss. 65-68.

54 „Religia (traktowana subiektywnie) jest poznaniem wszystkich naszych obowiązków jako przykazań Bożych”. RGV, AA 06:154-154. Por. KpV, AA 05:130; KU, AA 05:481, MS, AA 06:443 nn., 487, a także SF, AA 07:36. 
Brak teoretycznego rozstrzygnięcia co do istnienia Boga nie pozbawia jednak uwewnętrznionych nakazów moralnego prawa mocy przekonywania. Aby wywołać skutki, nie muszą one opierać się na autorytecie „zewnętrznego” prawodawcy (istniejącego, transcendentnego Boga). Jest dokładnie odwrotnie. Maksymy woli mogą wywołać moralne skutki tylko wtedy, gdy nie są niczym więcej niż uwewnętrznionym głosem obowiązku (Deus in nobis). Innymi słowy, człowiek działający „jakby” (instar) podlegał „zewnętrznemu” prawodawcy, w gruncie rzeczy działa w owym „drugim świecie”. Działa jako ens rationis pośród innych entis rationis. Bo tylko w takich warunkach na ludzkie serce imperatywy moralne działają bezpośrednio. Wystarczy więc jeśli możemy pomyśleć sobie taki porządek i składające się na niego elementy:

Musi być jednak również władza prawodawcza (potestas legislatoria) lub przynajmniej trzeba pomyśleć sobie taką władzę, która nadaje tym prawom [tzn. prawom moralnym T.K.] wyraz [Effect], aczkolwiek tylko w idei, która nie jest niczym innym, aniżeli tylko ideą najwyższej moralnej oraz fizycznej, wyniesionej ponad wszystko i potężnej istoty oraz jej świętej woli i uprawnia on do wniosku: Jest jeden Bóg ${ }^{55}$.

Fraza „tylko w idei” jest tu zastosowana w takim samym sensie, w jakim wystąpiła w Krytyce czystego rozumu, w odniesieniu do ideału transcendentalnego ${ }^{56}$. Efektywność praw moralnych nie jest gwarantowana fizyczną siłą (realną władzą), zdolną wyegzekwować ich przestrzeganie w tym świecie. Ewentualność tę należy wykluczyć ze względu na naturę samej moralności. Działanie egzekwowane przemocą nie miałoby moralnej wartości, ponieważ zewnętrzny wpływ na ludzką wolę pozbawiałoby ją autonomii. Jeśli jednak owa władza zostanie tylko pomyślana, a więc będzie władzą „tylko w idei”, to autonomia woli nie będzie zagrożona. Istnienie lub nieistnienie takiej władzy nie ma żadnego znaczenia.

Wypowiedzi Kanta, w których „istniejącemu” Bogu przeciwstawia się, jako wystarczającego, pomyślanego Boga „tylko w idei”, są potwierdzeniem radykalizacji stanowiska, która dokonała się w różnych aspektach późnego dzieła filozofa. Przykładem może być rezygnacja z moralnego dowodu istnienia Boga w Religii w obrębie samego rozumu, który we wcześniejszych pismach opierał się na pojęciu najwyższego dobra ${ }^{57}$. Innego przykładu dostarcza alegoreza biblijna, w której pomiędzy rokiem 1792 a 1798 - na pierwszy plan wysuwa Kant moralny sens litery tekstu $^{58}$. Kontynuacja tych procesów jest widoczna również w Opus postumum ${ }^{59}$, prowadząc do tego, co niektórzy autorzy nie wahają się nazywać „rozmyciem”

${ }^{55}$ OP, AA 22:126.

${ }^{56} \mathrm{KrV}, \mathrm{A}$ 577-578/B 605-606.

57 T. Kupś, Opus postumum Immanuela Kanta, s. 244 nn. Por. idem, Radykalizacja filozofii religii w późnych pismach Kanta, s. 149 nn.

${ }^{58}$ B. Stangneth, Kultur der Aufrichtigkeit. Zum systematischen Ort von Kants »Religion innerhalb der Grenzen der bloßen Vernunft«, Königshausen \& Neumann, Würzburg 2000, s. 239 nn.

59 T. Kupś, Opus postumum Immanuela Kanta, s. 269. 
pojęcia Boga ${ }^{60}$. Człowiek, podkreśla Kant, sam jest twórcą idei Boga ${ }^{61}$, z której następnie czyni hipostazę uwewnętrznionego poczucia obowiązku ${ }^{62}$, immanentną boskość praktycznego rozumu ${ }^{63}$.

\section{Idea Boga w Opus postumum}

Aby zilustrować konsekwencje tego stanowiska, posłużę się przykładem zaczerpniętym z Opus postumum. Karta dziesiąta, ze zbioru siódmego (Convolut VII), datowana niedokładnie, na okres pomiędzy kwietniem a grudniem 1800 roku $^{64}$, jak większość rękopisu ostatniej rozprawy Kanta, jest mozaiką notatek ${ }^{65}$. Niektóre fragmenty dają się rozpoznać jako prezentacja głównej myśli, inne jako jej uzupełnienie albo rozwinięcie. Zwrócę tu uwagę na niektóre z nich, opatrując prezentację przykładami zaczerpniętymi z innych pism Kanta.

W czwartym akapicie, pierwszej strony wspomnianej karty Opus postumum, Kant definiuje Boga wyłącznie za pomocą pojęcia obowiązku:

Istota, która zgodnie z prawem obowiązku (kategorycznym imperatywem) moralnie-praktycznego rozumu jest uprawniona i posiada możność, by rozkazywać wszelkim istotom rozumnym, jest Bogiem (ens summum, summa inteligentia, summum bonum) ${ }^{66}$.

Zwrot „rozkazywać wszelkim istotom rozumnym” jest tu kluczowy, ponieważ „panowanie” Boga rozciąga na obszar dający się opisać jako ogół istot, których rozumność wyraża się zdolnością do podlegania obowiązkom (imperatywom). Jeśli zaś imperatywy są tylko „przedstawieniami obiektywnej zasady” ${ }^{67}$, ale za to wystarczającymi do tego, by wolę zmusić do określonego działania, to znaczy, że człowiek (jako istota rozumna) jest zdolny działać pod wpływem tylko przedstawionych praw ${ }^{68}$. Człowiek, jak każda rzecz w przyrodzie, musi działać według

${ }^{60}$ A. Cortina, Die Auflösung des religiösen Gottesbegriffs..., s. $280 \mathrm{nn}$.

${ }^{61}$ OP, AA 22:105.

62 OP, AA 22:129-130.

${ }^{63}$ T. Kupś, Opus postumum Immanuela Kanta, ss. 272-275.

${ }^{64}$ Datowanie notatek Opus postumum (na podstawie Gerharda Lehmanna i Artura Buchenaua oraz korekt Burkharda Tuschlinga i Reinharda Brandta) podaję w Opus postumum Immanuela Kanta, ss. 61-63.

${ }^{65}$ Podsumowanie dotychczasowych badań nad nieukończonym dziełem Kanta zawiera: G.P. Basile, Kants Opus postumum und seine Rezeption, De Gruyter, Berlin 2013. Por. także T. Kupś, Opus postumum Immanuela Kanta, s. 60. Wyobrażenia na temat „mozaikowego” układu notatek Opus postumum nie da się wyrobić na podstawie drukowanych edycji. Jest to możliwe tylko na podstawie oryginalnego rękopisu, reprodukowanego obecnie w cyfrowej edycji, publikowanej w na stronach internetowych Berlin-Brandenburgische Akademie der Wissenschaften.

${ }^{66}$ OP, AA 22:116.

67 GMS, AA 04:413.

${ }^{68}$ GMS, AA 04:412. 
praw, ale nie jest ani tylko istotą naturalną, ani tylko istotą rozumną ${ }^{69}$. To znaczy że ani nie podlega tylko prawom przyrody, ani tylko prawom praktycznym, choć podlega jednym i drugim. Natomiast o Bogu pisze Kant, że nie podlega obowiązkowi, ale ma tylko prawa ${ }^{70}$. Człowieka nie wyróżnia więc to, iż „ma prawa”, to znaczy nie wyróżnia go to, że „działa według praw”71 (przypomnijmy, co już wyżej wspomniano, że według praw działa każda rzecz w przyrodzie ${ }^{72}$ ). Człowieka wyróżnia tylko to, że „ma obowiązki”73, że jest „Związany obowiązkiem”74, że „podlega obowiązkowi”75 itp. Człowieka nie definiują więc zdolności poznawcze, ale kompetencje moralne. To nie rozum teoretyczny czyni człowieka wyjątkowym pośród innych istot rozumnych, sprawia to raczej rozum praktyczny, który - jak czytamy na końcu Krytyki praktycznego rozumu - „przedstawia mnie [jako będącego] w świecie, który posiada prawdziwą nieskończoność, lecz może być ujęty tylko poprzez rozum"76.

Bóg, o jakim mowa w przywołanym wyżej fragmencie Opus postumum, panuje (wywiera skutki) tylko w inteligibilnej sferze obowiązków, nakładając je na istotę, która zdolna jest do tego, by obowiązkom tym podlegać i być nimi związaną w swoim działaniu. Można powiedzieć, że cała sfera oddziaływania tej tylko przedstawionej „siły, która zobowiązuje ogół istot rozumnych” sama jest - przeciwstawianym przyrodzie - Bogiem ${ }^{77}$. „Bóg” i „świat” nie oznaczają tu tylko uniwersum istot (istot rozumnych i istot fizycznych), choć to właśnie oznaczają w pierwszej kolejności ${ }^{78}$, ale przede wszystkim oznaczają ,jednoczące pryncypium”79, które ogół tych istot łączy i wiąże ${ }^{80}$. Bóg oznaczałby jedność istot rozumnych pod władzą obowiązku.

Istnieje Bóg, pisze Kant, „[p]onieważ jest siła, która zobowiązuje ogół istot

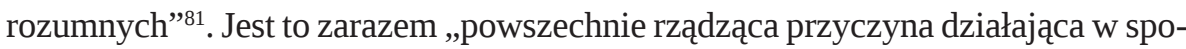
sób wolny w istotach rozumnych”82. Co jednak oznacza sformułowanie „istota

69 „Człowiek (istota w świecie) jest zarazem istotą posiadającą wolność, która jest właściwością całkowicie niezależną od kauzalnych zasad świata, a mimo to przynależy do człowieka”. OP, AA 21:42.

${ }^{70}$ OP, AA 21:43; OP, AA 22:49, 50.

${ }^{71}$ GMS, AA 04:412.

72 Przyroda bowiem oznacza po prostu „istnieniem rzeczy, o ile jest ono określone przez prawa powszechne”. Prol, AA 04:294.

${ }_{73}$ OP, AA 21:48, 55, 56, 77.

${ }^{74}$ OP, AA 21:77, 86.

75 OP, AA 21:82, 83, 94.

${ }^{76} \mathrm{KpV}$, AA 05:162.

77 Por. T. Kupś, Opus postumum Immanuela Kanta, s. 261.

${ }^{78}$ OP, AA 22:124; OP, AA 21:9, 43, 141.

${ }^{79}$ RGV, AA 06:97.

${ }^{80}$ T. Kupś, Opus postumum Immanuela Kanta, ss. 257-258.

${ }^{81}$ OP, AA 21:157.

${ }^{82}$ OP, AA 22:104. 
rozumna” (ens rationis)? Z pewnością nie oznacza istoty wymyślonej przez rozum (Entwurf czy Vernunftwesen) ${ }^{83}$, ale raczej istotę, której byt (ens) urzeczywistnia się w sferze inteligibilnej (określonej całkowicie przez rozum). Człowiek jako istota rozumna jest częścią takiego porządku i jest takim bytem (ens) wtedy i tylko wtedy, gdy działa „z obowiązku”, a więc pobudzony tylko przez „przedstawienie prawa”" ${ }^{4}$. Wtedy jego działanie w ogóle nie jest „ze świata”, ale jest działaniem w tym, co Kant w Opus postumum nazywa działaniem „w Bogu”: „W niej, idei Boga jako istoty moralnej, funkcjonujemy i jesteśmy; pobudzani przez poznanie

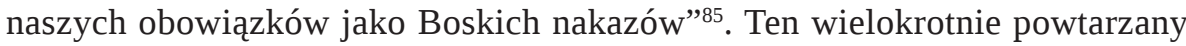
w Opus postumum zwrot ${ }^{86}$ jest parafrazą wersetu Dziejów Apostolskich ${ }^{87}$, będącego częścią opisu przemowy św. Pawła na Areopagu, potępiającej wszelkie formy bałwochwalstwa. Na gruncie filozofii Kanta potępianym bałwochwalstwem byłoby otoczenie boską czcią czegokolwiek poza rozumem praktycznym:

Jest Bóg. Albowiem jest kategoryczny imperatyw obowiązku, przed którym zginają się wszystkie kolana, zarówno w niebie, jak i na ziemi etc. A jego imię jest święte bez potrzeby przyjmowania, że istocie tej powinna przysługiwać jakaś substancja reprezentująca ją wobec zmysłów $[\ldots]^{88}$.

Albo w innym miejscu:

W duchu człowieka podstawowa zasada [Prinzip] moralnie-praktycznego rozumu jest nakazem obowiązku, który czuje się on zmuszony bezwarunkowo czcić i być mu posłusznym (obtemperantia) i który jest zgodny z imperatywem kategorycznym [...]. Idea takiej istoty, przed którą zginają się wszystkie kolana etc. wyrasta z tego imperatywu, a nie odwrotnie ${ }^{89}$.

Religia jest kultem istoty, przed którą każda inna zgina swoje kolana i której godności, jako jedynej, każda inna istota czuje się [zobowiązana] podlegaćc ${ }^{0}$.

Zwróćmy uwagę na sposób, w jaki o Bogu mówią kolejne fragmenty tej samej, dziesiątej karty siódmego zbioru Opus postumum:

${ }^{83}$ H. Klinge, Die moralische Stufenleiter..., s. $48 \mathrm{nn}$.

${ }^{84}$ „Dlatego owo doskonałe dobro nie może zaistnieć inaczej aniżeli w przedstawieniu prawa samego w sobie, pojawiającym się tylko u istot rozumnych, gdzie racją określającą ich wolę może być właśnie ono, a nie oczekiwany skutek”. GMS, AA 04:401.

${ }^{85}$ OP, AA 22:118.

${ }^{86}$ „W nim, przez tzw. jego wszechmocne stawanie się świata, żyjemy, działamy (poruszamy się) i jesteśmy agimus, facimus, operamus”. OP, AA 22:62. Por. także OP, AA 21:36 oraz OP, AA 22:55.

87 „Bo w Nim żyjemy, poruszamy się i jesteśmy, jak też powiedzieli niektórzy z waszych poetów: »Jesteśmy bowiem z Jego rodu«”. Dz 17,28.

${ }^{88}$ OP, AA 21:64.

${ }^{89}$ OP, AA 22:121-122.

${ }^{90}$ OP, AA 21:101. 
Istotą, która ma nieograniczoną moc nad przyrodą i wolnością, podległymi prawom rozumu, jest B ó g. Bóg jest zatem zgodnie ze swym pojęciem nie tylko istotą przyrodniczą, ale też moralną. Gdy rozpatruje się jedynie tę pierwszą własność [Qualität], jest on stwórcą świata (demiurgus) i jest wszechwładny. Gdy idzie o drugą, święty (adorabilis) i wszelkie ludzkie obowiązki są równocześnie jego nakazami. Jest on ens summum, summa intelligentia, summum bonum ${ }^{91}$.

Ta wypowiedź świadczy o tym, że Kant chce uniknąć wrażenia, jakoby podane wcześniej moralne znaczenie pojęcia Boga mogło usuwać jego metafizyczny sens. Moralne znaczenie zostaje raczej „dodane” do tradycyjnego ${ }^{92}$. Innymi słowy, Bóg jest wszystkim tym, co próbuje o nim powiedzieć tradycyjna metafizyka, ale nie jest tylko tym. Bóg jest bowiem również tym, co stara się o nim powiedzieć teologia moralna, w sensie, w jakim Kant realizuje ją od Krytyki czystego rozumu. W Opus postumum Kant rzeczywiście usiłuje wyjść poza demiurgiczne pojęcie Boga, jako stwórcy świata, ku idei „wszechmocnej moralnej istoty, której wola jest kategorycznym imperatywem dla wszystkich istot rozumnych”93.

Oto, co pisze Kant dalej:

Przy tym to, czy idea ta miałaby realność jako produkt naszego własnego umysłu, czy byłaby samą tylko rzeczą myślową (ens rationis) wydaje się pozostawać pytaniem [bez odpowiedzi], a nam nie pozostaje nic innego jak moralny stosunek do tego przedmiotu, który jest czysto problematyczny i który pozostawia tylko formułę poznania wszelkich ludzkich obowiązków jako (tanqvam) boskich nakazów, gdy kategoryczny i m peraty w obowiązku wydaje żelazny głos między syrenim wabieniem pobudek zmysłowych a strachem powodowanym przez groźby ${ }^{94}$.

Kant odróżnia vernünftige Wesen, tzn. byt inteligibilny, ideę od Vernunftwesen, „wytworu naszego myślenia”, na oznaczenie którego używa nawet słowa Dichtung (zmyślenie), stosowanego w odniesieniu do eteru hipotetycznego ${ }^{95}$, albo matematycznego modelu (Entwurf) ${ }^{96}$. Choć i to znaczenie „rzeczy myślowej” trudno jest od razu odrzucić, jeśli uwzględnimy wypowiedzi filozofa, w których definiuje filozofię transcendentalną, nazywając ją „ogółem (complexus) idei (zmyśleń [Dichtungen]) wszystkich zasad teoretycznie-spekulatywnego i moralnie-praktycznego rozumu w bezwarunkowej (absolutnej) całości pierwotnego samoustanowienia w syntetycznym poznaniu a priori z pojęć”97. O tych „zmyśleniach” mówi Kant jako o niere-

91 OP, AA 22:116-117.

92 Analogicznie, na gruncie etycznej alegorezy biblijnej, Kant dodaje moralny sens do tekstu, który go literalnie nie zawiera albo jest z nim sprzeczny. Por. T. Kupś, Immanuela Kanta wykładnia tekstu Biblii, „Filo-Sofija” 2006, nr 6, s. 67 nn.

93 OP, AA 22:127.

94 OP, AA 22:117.

95 OP, AA 21:215, OP, AA 22:383. Por. H. Klinge, Die moralische Stufenleiter..., s. 43 nn.

96 OP, AA 22:490.

97 OP, AA 21:89. Por. OP, AA 21:101. 
alnych, choć uzasadnionych ${ }^{98}$. Uzasadnienie, o jakie w tym przypadku chodzi, jest jednak tylko formalne i praktyczne („pozostawia tylko formułę poznania wszelkich ludzkich obowiązków jako (tanqvam) boskich nakazów"999). Zapewne to właśnie ma na myśli Kant, gdy mówi o praktycznej realności tej idei: „Bóg jest czystą ideą rozumu, ale posiadającą największą wewnętrzną i zewnętrzną praktyczną realność”100.

Nie mając jednak nic więcej poza obowiązkiem, który w maksymie przedstawia prawo praktyczne, tylko formalnie, w postaci nakazu boskiego autorytetu (a więc „jako”, instar, boskiego przykazania), mam jednak wystarczająco wiele, by bezbłędnie ominąć Scyllę „pobudek zmysłowych” i Charybdę „gróźb”. Posłuszeństwo wobec moralnego prawa nie jest wyrazem ani słabości, ani strachu, ale siły i pewności wiary, która nie ustępuje pod naciskami i nie ulega zachętom. W taki sposób Kant rozumie i interpretuje w pismach z lat 90. świadectwa moralnej pewności wyrażone w biblijnych opowieściach ${ }^{101}$. Historie Hioba i Abrahama są dla Kanta przykładami nieomylności wewnętrznego osądu rozumu praktycznego ${ }^{102}$. W Opus postumum powtarza je niemal w niezmienionej postaci ${ }^{103}$.

\section{Podsumowanie}

Nawet jeśli część wypowiedzi filozofa na temat Boga w Opus postumum można uważać za konsekwentne podtrzymanie ustaleń zawartych we wcześniejszych pismach, wiele z nich wyróżnia zmiana akcentu, który zostaje teraz przeniesiony na Boga jako ideę. Kant pisze na przykład: ,jedna tylko idea Boga jest dowodem jego istnienia”, a na marginesie dodaje: „bytu Boga udowodnić nie można”104. Teza „jest Bóg” sąsiaduje z twierdzeniem: „my sami tworzymy sobie tę ideę”105. W innym miejscu Kant oświadcza, że „Boga należy sobie przedstawiać nie jako substancję poza mną, ale jako najwyższą moralną zasadę we mnie”106, a w innym miejscu: „Bóg nie jest istotą poza mną, ale tylko ideą w mnie”107.

\footnotetext{
98 „die zwar an sich gegründe [...] seyn”. OP, AA 21:105.

99 OP, AA 22:117.

100 OP, AA 21:142; por. OP, AA 21:27-28.

101 SF, AA 07:63, przypis.

102 SF, AA 07:48. Por. T. Kupś, Opus postumum Immanuela Kanta, s. 249 nn.

103 „Nie ma wątpliwości co do tego, że święta, posiadająca władzę istota naprawdę nie wydała ani nakazu, ani zakazu ludziom, i że nawet gdyby to się stało, ludzie, którym zostały one wydane, nie mogliby tego głosu usłyszeć i przekonać się o jego prawdziwości, [toteż] nie pozostaje nic innego jak poznanie naszych obowiązków jako in star Boskich nakazów, które też przy nieuniknionej niewiedzy co do takiego obwieszczenia nie tracą nic ze swego autorytetu. Imperatyw moralny może być więc uważany za głos Boży”. OP, AA 22:64.

104 OP, AA 21:14-15.

105 OP, AA 21:51.

106 OP, AA 21:144.

107 OP, AA 21:145.
} 
O ile w późnych pismach okresu krytycznego można byłoby mówić o czymś w rodzaju „uwznioślenia” chrześcijańskiego wyobrażenia Boga jako prawodawcy moralnego, to w Opus postumum Bóg-prawodawca niejako traci całkowicie swoje chrześcijańskie zakorzenienie. Jest już tylko ideą rozumu, wyłącznie bytem myślowym. Znamienne jest, że Kant określa w taki sam sposób materię ciepła, którą również nazywa Gedankending (rzeczą dającą się tylko pomyśleć; rzeczą intelligibilną $)^{108}$. Pisze o niej również, że jest „bytem [Wesen] wymyślonym”109 albo „ideą”110. Uznanie materii ciepła, z jednej strony, za rzecz czysto intelligibilną, z drugiej zaś odrzucenie rozpatrywania jej jako hipotezy wydaje się nawet jakimś paradoksem ${ }^{111}$. W gruncie rzeczy jest to jedynie pozorna niekonsekwencja. Hipoteza ma bowiem zastosowanie empiryczne, jest zakładana ze względu na określone zjawiska, dla których stanowi doraźną rację wyjaśnienia ich natury ${ }^{112}$. Prawa przyrody formułowane są w oparciu o hipotezy, które podlegają weryfikacji w doświadczeniu. Hipotezy są modelami, stanowiącymi podstawę wyjaśnienia określonych zjawisk. Natomiast niehipotetyczna materia ciepła jest transcendentalnym warunkiem wszelkiego doświadczenia. Oczywiście nie przestaje przez to być „rzeczą intelligibilną” czy „ideą”, której status jest całkowicie „nieteoretyczny”. Podobnie idea Boga, która daje się tylko pomyśleć, jest teoretycznie niedowodliwa, ma jednak praktyczną realność. Eter nie jest ani tylko „tymczasowym”, ani tylko „przygodnym” założeniem, ale jest warunkiem podstawowym i nieusuwalnym, condicio sine qua non doświadczenia w ogóle. Status tak rozumianej, „dającej się tylko pomyśleć” materii jest zbliżony do statusu, jaki w systemie filozofii Kanta zajmuje idea Boga:

Jeśli nawet Bóg ma być w filozofii rozpatrywany jako rzecz dającą się pomyśleć [Gedankending] (ens rationis), to [pojęcie takie] oraz wszystkie przypisywane mu predykaty czystego rozumu, które analitycznie wynikają z tej idei, trzeba ustanowić w sposób konieczny; niezależnie od tego, czy istnienie [existire] takiej substancji przyjmie się, czy też nie ${ }^{113}$.

W Krytyce czystego rozumu Kant stwierdza, że „,[w] celu przedstawienia sobie całkowitego określenia rzeczy, nie musimy zakładać istnienia istoty, która odpowiada temu ideałowi, ale tylko id eę takiej istoty"114. To znaczy, że wystar-

\footnotetext{
${ }^{108}$ OP, AA 21:604; OP, AA 22:106.

109 OP, AA 21:544.

110 OP, AA 21:574.

111 V. Mathieu, Kants Opus postumum, ss. 116-117.

112 T. Kupś, Opus postumum Immanuela Kanta, s. $192 \mathrm{nn}$.

113 OP, AA 21:32.
}

114 Por. E. Förster, Kant’s Final Synthesis..., s. 81. Odnośny fragment Krytyki czystego rozumu brzmi: „Rozumie się samo przez się, że rozum przy tym swoim zamiarze, by mianowicie wyobrazić sobie konieczne i wyczerpujące określenie rzeczy, nie zakłada bynajmniej istnienia [Existenz] takiej istoty, która odpowiadałaby ideałowi, ale tylko ideę, ażeby z bezwarunkowej totalności wyczerpującego określenia wyprowadzić [całość] uwarunkowaną, tj. całkowitość tego, 
czy, jeśli podstawa kolektywnej jedności doświadczenia jest ideą, dającym się pomyśleć czystym pojęciem. Jeśli zaś istnieje tylko jedno doświadczenie i tylko jeden systematyczny związek wszystkich spostrzeżeń, to musi być również dany ogół (całość) materii naszych spostrzeżeń ${ }^{115}$. „Materią”, którą „należy przyjąć”, ma być właśnie transcendentalny eter. Tym zaś, czym w filozofii teoretycznej jest eter (któremu w Krytyce czystego rozumu odpowiadał ideał transcendentalny), tym w filozofii praktycznej jest idea Boga. Jeśli zaś uwzględnimy fakt, że ideał transcendentalny, w wyniku naturalnego, ale wiodącego na manowce, hipostazowania, może (lecz nie musi) zostać przekształcony w ideę Boga, to dojdziemy do paradoksalnego wniosku o - przynajmniej funkcjonalnej - odpowiedniości pojęcia eteru transcendentalnego i transcendentalnej idei Boga w późnej filozofii Kanta. Materiał do nieukończonego dzieła, które miało opisać tę zmianę, został zebrany w Opus postumum, dając świadectwo kierunku, w jakim zmierza rozkład tradycyjnego pojęcia Boga. Jedno z możliwych znaczeń wskazuje na rozumienie tej idei przez Kanta jako obszaru realizacji moralnego postępowania, rozumianego jako skutek ograniczania wszystkich możliwych działań przez prawo moralne $\mathrm{e}^{116}$.

\section{Literatura}

Basile G.P., Kants Opus postumum und seine Rezeption, De Gruyter, Berlin 2013.

Biblia Tysiq̨clecia, Pismo Święte Starego i Nowego Testamentu, Pallotinum, Poznań 2003. Bobko A., Kant i Schopenhauer. Między racjonalnościq a nicościq, Wydawnictwo Wyższej Szkoły Pedagogicznej, Rzeszów 1996.

Bobko A., Religijny fundament filozofii politycznej Kanta?, w: Kant wobec problemów współczesnego świata, red. J. Miklaszewska i P. Spryszak, Wydawnictwo Uniwersytetu Jagiellońskiego, Kraków 2006.

Bohatec J., Die Religionsphilosophie Kants in der Religion innerhalb der Grenzen der bloßen Vernunft, Hoffman und Campe, Hamburg 1938.

Brandt R., Der Gott in uns und für uns bei Kant, w: red. C. Bickmann, M. Wirtz, H.-J. Scheidgen, Religion und Philosophie im Widerstreit?, Bautz, Nordhausen 2008.

Brinkmann W., Praktische Notwendigkeit. Eine Formalisierung von Kants Kategorischem Imperativ, Mentis, Paderborn 2003.

Cassirer E., Kants Leben und Lehre, Bruno Cassirer, Berlin 1921.

Chlewicki Maciej, Kant a problem filozofii religii, Wydawnictwo Uniwersytetu Kazimierza Wielkiego, Bydgoszcz 2012.

co ujęte jest w szranki. Ideał jest więc dla niego prawzorem (prototypon) wszechrzeczy, które razem wzięte, jako ułomne kopie (ectypa), czerpią z niego tworzywo dla swej możliwości. I choć w mniejszym lub większym stopniu zbliżają się do owego ideału, to przecież zawsze pozostają nieskończenie dalekie od dosięgnięcia go”. KrV, A 577-578/B 605-606.

${ }^{115} \mathrm{KrV}, \mathrm{A}$ 582/B 610.

${ }^{116} \mathrm{~W}$ tym podsumowaniu niemal dosłownie powtarzam tezy zawarte w mojej wcześniejszej publikacji (por. Opus postumum Immanuela Kant, ss. 229-233). Poprzedzam je jednak tutaj innymi argumentami. 
Cortina A., Die Auflösung des religiösen Gottesbegriffs im Opus postumum Kants, „Kant-Studien” 1984, nr 3(75).

Dierksmeier C., Das Noumenon Religion. Eine Untersuchung zur Stellung der Religion im System der praktischen Philosophie Kants, De Gruyter, Berlin-New York 1998.

Edwards R. B., Reason and Religion, University Press of America, Washington 1979.

Eisler R., Kant-Lexikon, Olms, Hildesheim-Zürich-New York 1994.

Fischer K., Immanuel Kant und seine Lehre, Winter, Heidelberg 1957.

Förster E., Kant's Final Synthesis. An Essay on the Opus postumum, Harvard University Press, Cambridge-London 2000.

Heine H., Z dziejów religii i filozofii w Niemczech, tłum. T. Zatorski, Zakład Wydawniczy Nomos, Kraków 1997.

Kant I., Dzieła zebrane, Wydanie Translatorium Filozofii Niemieckiej IF UMK pod kierunkiem Mirosława Żelaznego, t. 1-6, Wydawnictwo Naukowe Uniwersytetu Mikołaja Kopernika, Toruń 2010 i nast.

Kant I., Opus postumum, tłum. Tomasz Kupś, Mirosław Żelazny, Wydanie Translatorium Filozofii Niemieckiej IF UMK pod kierunkiem Mirosława Żelaznego, Wydawnictwo Naukowe Uniwersytetu Mikołaja Kopernika, Toruń 2019.

Kant's gesammelte Schriften, herausgegeben von der Preussischen Akademie der Wissenschaften, Bd. 21, 22, Walter de Gruyter \& Co, Berlin und Leipzig 1936, 1938.

Klinge H., Die moralische Stufenleiter. Kant über Teufel, Menschen, Engel und Gott, De Gruyter, Berlin-Boston 2018.

Kuehn M., Kant. A Biography, Cambridge University Press, Cambridge 2001.

Kupś T., Immanuela Kanta wykładnia tekstu Biblii, „Filo-Sofija” 2006, nr 6.

Kupś T., Od ontoteologii do krytyki dowodu ontologicznego - ewolucja myśli Immanuela Kanta, w: Dowody ontologiczne. W 900. Rocznicę śmierci św. Anzelma, red. S. Wszołek, Kraków 2011.

Kupś T., Ofiarowanie Izaaka w interpretacji Kanta i Kierkegaarda, w: Immanuel Kant i świat współczesny. W 200. rocznicę śmierci Immanuela Kanta, red. K. Śnieżyński, Uniwersytet im. Adama Mickiewicza, Wydział Teologiczny, Poznań 2004.

Kupś T., Opus postumum Immanuela Kanta, Wydawnictwo Naukowe Uniwersytetu Mikołaja Kopernika, Toruń 2016.

Kupś T., Radykalizacja filozofii religii w późnych pismach Kanta, w: Znaczenie filozofii Oświecenia. Człowiek wśród ludzi, red. B. Grabowska, A. Grzeliński, J. Żelazna, Toruń 2016.

Kupś T., Religia rozumowa a wiara kościelna w filozofii Immanuela Kanta, w: Filozofia Boga, red. ks. S. Janeczek, A. Starościc, cz. 1: Poszukiwanie Boga, Wydawnictwo KUL, Lublin 2017.

Langthaler R., Kant über den Glauben und die »Selbsterhaltung der Vernunft«. Sein Weg von der »Kritik« zur »eigentlichen Metaphysik« - und darüber hinaus, Karl Alber, Freiburg-München 2018.

Lehmann G., Kants Tugenden. Neue Beiträge zur Geschichte und Interpretation der Philosophie Kants, De Gruyter, Berlin-New York 1980.

Mathieu V., Kants Opus postumum, Vittorio Klostermann, Frankfurt am Main 1989.

Palmquist S., Does Kant Reduce Religion to Morality?, „Kant-Studien” 1992, nr 2(83).

Sala G., Kant und die Frage nach Gott. Gottesbeweise und Gottesbeweiskritik in den Schriften Kants, De Gruyter, Berlin-New York 1990. 
Schopenhauer A., Czworaki korzeń zasady racji dostatecznej, tłum. J. Marzęcki, Antyk, Kęty 2003.

Schwarz G., Est Deus in nobis. Die Identität von Gott und reiner praktischer Vernunft in Immanuel Kants Kritik der praktischen Vernunft, Verlag TU Berlin, Berlin 2004.

Sirovátka J., Ethik und Religion bei Immanuel Kant. Versuch einer Verhältnisbestimmung, Karl Alber, Freiburg-München 2019.

Staeps H., Das Christusbild bei Kant, „Kant-Studien” 1907, nr 12.

Stangneth B., Kultur der Aufrichtigkeit. Zum systematischen Ort von Kants »Religion innerhalb der Grenzen der bloßen Vernunft«, Königshausen \& Neumann, Würzburg 2000.

Steigleder K., Kants Moralphilosophie. Die Selbstbezüglichkeit reiner praktischer Vernunft, Metzler, Stuttgart-Weimar 2020.

Tomaszewska A., Filozofia religii Kanta w kontekście nowożytnego racjonalizmu religijnego, „Studia z Historii Filozofii” 2020, nr 1(11).

Kant-Lexikon, red. M. Willaschek, J. Stolzenberg, G. Mohr, S. Bacin, De Gruyter, Berlin-Boston 2015.

Wimmer R., Kants kritische Religionsphilosophie, De Gruyter, Berlin-New York 1990. 